Branko Rakita
Vladan Madić $^{2}$
Dušan Marković
JEL: F69, M16

DOI: 10.5937/industrija45-11848

UDC: $338: 339.137 .2$

005.51:629.33

Original Scientific Paper

\title{
Competitive strategies of late followers in auto industry: case study Hyundai-Kia
}

\author{
Article history: \\ Received: 21 September 2016 \\ Sent for revision: 17 October 2016 \\ Received in revised form: 23 January 2017 \\ Accepted: 23 January 2017 \\ Available online: 5 April 2017
}

Abstract. This paper analyzes competitive strategy of late followers in auto industry in the case of Hyundai Kia Auto Group (HKAG). The global economic crisis has had a strong impact on the leaders in auto industry. HKAG took advantage of the crisis and increased sales and global market share at the expense of the leaders in the industry. We found that during the crisis the company achieved excellent results thanks to innovative marketing and sales strategies combined with top quality, product design and productivity. Growing competition and changes in business environment in the post-crisis period jeopardized the future growth of the company. The company reacted to the changes in business environment by shifting the focus to the luxury segment and green vehicles, by launching independent luxury brand Genesis and by scaling up investment in $R \& D$.

Key words: Auto industry, Hyundai-Kia, internationalization, global economic crisis, competitive strategies, late followers.

\section{Konkurentske strategije kasnih sledbenika u auto industriji : primer Hyundai-Kia}

Apstrakt. Rad analizira strategiju konkurentnosti kasnih sledbenika $u$ auto industriji na primeru Hyundai Kia Auto Group (HKAG). Globalna ekonomska kriza ostavila je snažne posledice na lidere $u$ auto industriji. HKAG je iskoristila krizu i povećala prodaju i globalnu tržišno učešće na teret lidera u grani. Utvrdili smo da je u periodu krize kompanija odlične poslovne rezultate

\footnotetext{
${ }^{1}$ University of Belgrade, Faculty of Economics

${ }^{2}$ Metropolitan University Belgrade, Faculty of Management

${ }^{3}$ University of Belgrade, Faculty of Economics, dusanm@ekof.bg.ac.rs 
Rakita B. et al.: Competitive strategies of late followers in auto industry: case study...

ostvarila zahvaljujući inovativnom marketingu $i$ prodajnim strategijama $u$ kombinaciji sa vrhunskim kvalitetom, dizajnom proizvoda i produktivnošću. Rast konkurencije i promena poslovnog ambijenta u postkriznom periodu ugrozili su dalji rast kompanije. Kompanija je na promene u poslovnom okruženju reagovala pomeranjem fokusa na segmente luksuznih $i$ zelenih vozila, osamostaljivanjem luksuznog brenda Genesis $i$ većim ulaganjem $u$ $R \& D$.

Ključne reči: Auto industrija, Hyundai-Kia, internacionalizacija, globalna ekonomska kriza, konkurentske strategije, kasni sledbenici.

\section{Introduction}

Growing integration of national economies in the past two decades has significantly facilitated and sped up the diffusion of innovation on the global level. At the same time, certain emerging markets have become the most vibrant part of the global economy. Thanks to this, the number of multinational companies from emerging markets is constantly increasing. Thus the list of Fortune Global 500 in 2016 contained 102 companies from China, 15 companies from South Korea, 7 companies from India, 6 Brazilian and 5 Russian companies. The first wave of internationalization of these companies mainly happened in labor-intensive industries (Rugman, 2009) and in recent years, these companies challenged the leaders in technology-intensive industries (Samsung, LG, Lenovo, Huawei, Embraer, etc.). Automotive industry is one of the last technology-intensive industries where the late followers from emerging markets seek to jeopardize the leader's position.

During the global economic crisis and in the post-crisis period, automotive industry has suffered significant changes. Car companies are facing more informed consumers, and energy efficiency, technology and safety are gaining in importance. Unfreezing of five competitive forces in the industry along with the financial problems of some leaders opened up the opportunity for challengers to improve their market positions.

This paper analyzes the strategy of late followers in automotive industry during the global economic crisis and in the post-crisis period. The analysis is based on HKAG case study. The paper consists of five sections. The first part is a literature review of follower strategies used by MNCs from emerging markets. Methodology for collecting and processing the data is presented in the next section. The third part examines HKAG's sources of competitiveness, especially at the beginning of the global economic crisis. The fourth part analyzes the changes in the company's business strategy during the global economic crisis and realization of business opportunities arising in this period. Finally, the last part of this paper deals with the company's operations in the 
Rakita B. et al.: Competitive strategies of late followers in auto industry: case study...

post-crisis period and its attempt to expand to higher market segments such as the segments of luxury and green vehicles. In accordance with the discussed theoretical concepts, several research statements were tested in this paper.

The first research statement assumes that the late followers from emerging markets use the strategy of low cost with acceptable quality of products at the beginning of internationalization in order to service the value for money segment.

The second research statement is that the late followers from emerging markets are faster than the leaders and remain extremely lean despite its size.

The third research statement assumes that the late followers in auto industry invest less in R\&D and have lower brand value compared with the leaders.

Finally, the fourth research statement assumes that the companies which want to challenge the leaders in auto industry have to make a shift towards higher market segments, such as luxury and green vehicles.

\section{Literature review}

The pace of growth is a widely examined question in the literature and instability of the global business environment has made it even more topical in the recent years. MNCs have at their disposal a pioneer and follower strategy. There are two forms of follower strategy: early and late followers. Lieberman and Montgomery (1988) in their award-winning work identified the following as the shortcomings of pioneering strategies and advantages of follower strategies: 1. The effect of free riding 2. Technological and marketing uncertainty, and 3. Pioneers' inertness that enables followers to infiltrate the market easier.

In order to realize innovation, pioneers must invest in development of supporting infrastructure and education of stakeholders, which represent the public good accessible to followers who do not take any risks and investments (Luo, 2002). Due to technological and marketing uncertainty, the pioneers are faced with the challenge of creating demand for unknown products, and brands sometimes (Kaličanin, 2008). Followers often possess complementary resources that enable commercialization of initial innovation, while the pioneers lack these resources or become financially and marketing exhausted after innovation's launch (Becerra, 2009). Pioneers' inertness mainly occurs due to the high investment in specific fixed assets, unwillingness to leave the existing production lines and organizational inflexibility due to excessive growth (Lieberman and Montgomery, 1988). Boulding and Christen (2001) 
Rakita B. et al.: Competitive strategies of late followers in auto industry: case study...

argued that pioneers' financial performances over the long term lag in relation to the performances of followers, due to the pioneers' inertness.

Success of the follower will be determined by the pioneer's business strategy and the available resources, as well as the development of the industry over time. If technological pioneering is supported by heavy investment in R\&D, logistics and promotion, pioneers will achieve better performance than companies with a strategy of wait and see (Isobe, Makino \& Montgomery, 2000). Pace of technological change in the industry and the growth in demand for the product or service will affect the success of a follower strategy (Suarez \& Lanzolla, 2005). In the case of rapid growth in demand and frequent changes in technology, it is difficult for pioneers to maintain the initial competitive advantage (Suarez \& Lanzolla, 2007), which is the case in technology-intensive industries with sophisticated customers (smart phones, video games, software, etc.). Auto industry is characterized by relatively high, though fluctuating demand growth and incremental technology changes, which could be interesting to challengers. However, the industry is very capital intensive, and production and supplier chain management is complex, so some researchers think that the existing leaders will dominate in the industry in the forthcoming period of time (MacDuffie \& Fujimoto, 2010).

Companies have to be innovative to achieve sustainable competitive advantage. Innovation capabilities of a company depend on possession of valuable, rare, and inimitable resources (Barney, 1991) which can be achieved through 1. internal development 2. strategic partnership 3. acquisitions (Barney \& Tong, 2006).

The first theories of business internationalization argue that companies from emerging markets are not able to innovate and that they are only capable of producing standardized products (Vernon, 1966). However, in the recent years the opinions that these companies can create only incremental innovations have emerged (Abrami, Kirby \& McFarlen, 2014). Recent business success of MNCs from emerging markets in technology intensive industries questions these conclusions and shows that they even have the capabilities to generate disrupting innovation. Emerging markets MNCs combine own strategic resources, strategic advantage of domestic market and market base resources from developed countries to achieve and sustain competitive advantage (Barnard, 2010). This strategy leads to improvement of MNC's absorptive capacity. Consequently, MNCs become able to assimilate and adapt external knowledge and increase their innovation capabilities ( $\mathrm{Li}$, $\mathrm{Li}$, \& Shapiro, 2012).

Emerging market governments promoted cooperation between local companies and MNCs from developed countries as a tool for improving innovation capabilities. This approach developed networking capabilities in companies from emerging markets and enabled them to identify quality 
Rakita B. et al.: Competitive strategies of late followers in auto industry: case study...

strategic partners and their strategic resources and to obtain these resources and use them in local conditions. The necessary resources are obtained through formal and informal networks (Luo, Sun, \& Wang, 2011). These resources are used as a base for developing internal strategic resources and for boosting internationalization.

As late followers, companies from emerging markets are increasingly using cross-border acquisitions of well positioned targets to bridge the gap between themselves and the leaders. Thus they gain technological solutions and other intangible assets necessary for business model restructuring (Christensen, Alton, Rising \& Walderck, 2011). Acquisitions aimed at business model restructuring carry the following risks: 1 . acquisition of target with inadequate resources 2 .how to properly assess the target and 3 . how to properly integrate the target. Due to all this they are recognized as acquisitions that often destroy value (Beishaar, Knight \& Van Wassenaer, 2001). However, the latest research suggests that acquisitions where emerging markets MNCs are investors contribute to value creation (Ray \& Gubbi, 2009; Gubbi, Aulakh, Ray, Sarkar \& Chittoor, 2010). High success rate of cross-border acquisitions made by MNCs from emerging markets is explained by complementarity of acquirers' resources and the resources possessed by targets from developed markets. These targets provide access to developed markets and customers with higher purchasing power, which implies higher profit margins, access to new technological solutions, globally recognizable brands, distribution channels and superior managerial and marketing competence (Kale, 2009). On the other hand, the targets gain access to low-cost manufacturing capabilities, inexpensive capital, and a large and growing demand in emerging markets (Knoerich, 2010).

MNCs from emerging markets combine acquired strategic resources with their own low cost production capabilities which enables them to simultaneously execute the strategies of differentiation and low cost (hybrid strategy). Hybrid strategy is reflected in offering technologically intensive products and wide range of products tailored to customer needs with minimal price increase (Williamson, 2010).

\section{Research methodology and data}

The research methodology is based on an individual case study of the late follower in automotive industry. The data presented in the official annual reports, presentations given to investors and sustainability reports delivered by Hyundai Motor Company, Kia Motors, Toyota Motor Company and Volkswagen were used. The data released by individual auto companies are combined with the data released by professional associations and specialized 
Rakita B. et al.: Competitive strategies of late followers in auto industry: case study...

institutions such as OICA, IHS, Jato Dynamics, JD Power, KAMA, Interbrand and KAIDA. Such approach added strength to the findings of this research, although the nature of the data did not permit statistical interference. Despite this limitation, the research yielded some very interesting results different from the findings of previous studies and theoretical models.

\section{Sources of competitiveness of HKAG as a late follower in auto industry}

Hyundai Motor Company $(\mathrm{HMC})$ is the largest South Korean car manufacturer founded in 1967 with headquarters in Seoul. In 1998, after the Asia-Pacific crisis, Hyundai took over Kia Motors, the second largest Korean auto manufacturer, and formed Hyundai-Kia Automotive Group.

According to OICA data for 2014, HKAG group was the fourth largest manufacturer of motor vehicles (somewhat over 8 million units), and the third largest car manufacturer in the world (somewhat over 7.6 million units). HMC made a larger share of the group's sales, selling almost 5 million units in 2014, while the rest referred to Kia Motors. Global market share of HMC in 2014 amounted to $5.7 \%$, an increase of 1.7 percentage points compared to 2008 (HMC, 2016a). Domestic market is extremely important to both companies in the group. According to KAIDA, HKAG sold more than 1.1 million vehicles in South Korea in 2014 and controlled almost $70 \%$ of the market. In 2014 sales network comprised 6,200 dealers in nearly 200 countries (HMC, 2015a). Besides the car manufacturers, HKAG also includes financial division Hyundai Finance that offers leasing possibilities and customer credits, and vertically integrated suppliers like Hyundai Mobis, Hyundai Wia, Hyundai Rotem, Hyundai Steel etc.

As a late follower, HMC spent almost 30 years building their position of a challenger of competitors from the US, Europe and Japan. Development of Toyota is the model of evolutionary development that HMC follows. Shankar, Krishnamurthi and Carpenter (1998) identified two possible approaches to narrowing the gap between late followers and pioneers. The first relates to building competitiveness through lower prices and increased investment in marketing mix elements, while the second relates to investment in innovation and modification of competitive environment in order to create own pioneering advantages. HKAG has so far used the first approach with a focus on organic growth, commitment to quality and customer satisfaction, and achieving operational efficiency in production and development. The company is expected to move to the second approach in the near future by investing in development of green and safety technologies and launching an independent premium brand. 
Rakita B. et al.: Competitive strategies of late followers in auto industry: case study...

HKAG gained its competitive advantage through its experiences and learning processes in international markets (Ritter, 2010). Although the strategy of internationalization was largely evolutionary, the company was not oriented towards the less developed neighboring markets, which is a significant deviation from the initial theoretical model (Johanson \& Vahlne, 1977). From the beginning of internationalization, the company has been focused on developed markets of the US and Western Europe, while its production has been highly concentrated in the home country and other developing countries with relatively cheap labor force. Production facilities serve local markets, but are also used as an export platform for servicing neighboring markets.

In 1990s the company applied global business strategy which is primarily aimed at cost reduction (Chung, 2014), based on a high concentration of production in domestic market. In 2000 the company gradually switched to transnational strategy. The emphasis is on "multi-domestic structure" which is based on production sites located in different regions, i.e. diversification of production (Chung, 2014). In 2002 the company set up a joint venture with Chinese company BAIC with the aim to serve Chinese market. After that, the company established a larger number of manufacturing plants abroad, mainly in less developed countries: India, Czech Republic, Turkey, Russia and Brazil (HMC, 2016b). Manufacturing facility in Alabama, established in 2005 with the aim of serving the US market, is the only one operating in a developed country. According to Kim (2015), the company has transformed their domestic-oriented production structure to an overseas-oriented production structure more quickly than Toyota. This confirms that the company has the organizational capability to successfully transfer the production system used in their Korean factories to foreign affiliates, regardless of the specific local factors. Saturated domestic market and rapid growth of emerging economies have been the main reasons for the change in production structure (Kim, 2015).

The extensive manufacturing network in developing countries provides HMC with balanced global presence, reduces dependence on the US and European markets that have been the most severely hit by the global economic crisis, and lowers operating costs due to cheaper labor force and other local inputs. At the same time, the global production network reduces the company's exposure to foreign exchange risk, increases production flexibility, enables the company to adapt faster to fluctuations in demand and to launch a model tailored to local preferences more quickly. Due to all that, the production capacities abroad grew, while domestic production stagnated (Chung, 2011). The company internationalized R\&D function too. Their R\&D centers are located in South Korea, Germany, China, Japan, India and the US, while the design centers are located in South Korea, US, Germany, China, Japan and India. The goal is to develop and customize design, key technologies and products to local demand. 
Rakita B. et al.: Competitive strategies of late followers in auto industry: case study...

The company's competitiveness is based on giving equal importance to quality and prices below the competitors', accompanied by high operational efficiency and significant investment in marketing. On the basis of Porter's competitive strategy the company derives its competitiveness from low operating costs. Operational efficiency stems from a hybrid production system that combines elements of Ford and Toyota's production systems and specific institutional environment in South Korea. The company builds the technological and organizational capabilities where engineers are innovators, not workers as in Toyota Production System (Lee \& Jo, 2006). Some critics believe that the success of HKAG is based on the "exploitation" of workers and small suppliers, and that militant labor unions and frequent stoppages and worker strikes caused by "low road" strategy of human resources management pose risk to the competitiveness (Chung, 2011). Innovations focused on efficiency are based on maximization of flexible automation in production and minimization of worker involvement (Chung, 2014). Global competitiveness of $\mathrm{HMC}$ is based on the superior cost structure where there is a combination of low cost materials and labor, flexible automated production driven by demand and organizational efficiency which allows great agility and speed (Ritter, 2010). This allows achieving the desired economies of scale and quality products (Fujimoto, 2001).

For several years now, the company has shifted to higher market segments and has been using differentiation strategy to increase market share and profit margins. According to Boyer and Freyssenet (2006), in terms of profit strategies, HKAG replaced "volume" strategy with "volume and diversity strategy". Differentiation in auto industry implies a variety of products and services, innovation, excellent quality and design, and management of higher prices. Software and electronics have become an increasingly important source of differentiation in auto industry in recent years. HKAG improves the performance of its premium cars via innovation, i.e. by using cheaper software solutions and electronics instead of costly mechanical parts without impairing the performance and comfort. However, the company is lagging behind the leaders in the industry in terms of the degree of product differentiation, which is reflected in a smaller range of models, smaller number of variations of a model and narrow range of engines.

According to the McKinsey Global Institute (2015), technological and organizational innovations have enabled the company to become a leader in productivity, which is the key indicator of competitiveness in auto industry. In 2013, the company had the highest output per worker, i.e. 47 vehicles per worker, while Toyota's productivity reached 27 vehicles per worker and VW's stood at only 20 vehicles per worker. By comparison with its competitors, the company has the smallest number of production locations and the lowest number of workers. Nevertheless, its output per location is by far the largest (HMC, 2015a; Toyota, 2014; Volkswagen, 2015). 
Rakita B. et al.: Competitive strategies of late followers in auto industry: case study...

\section{HKAG's business strategy of a late follower during the global economic crisis}

Crises have a devastating impact on automotive industry because customers are hesitant to buy new cars due to the general uncertainty, job cuts, lower credit standing and lack of favorable car loans for new vehicles. Declining demand requires optimization of $R \& D$, production and supply chain processes in automotive companies. According to OICA, 2009 was one of the toughest years for automotive industry because sales fell by almost six million vehicles, or more than $8 \%$, compared with the pre-crisis year 2007 . The decline in sales was particularly pronounced in the US market and in Europe, which resulted in financial and business restructuring in the industry. On the other hand, there was a tremendous growth in production and sales in large developing countries such as China, India and Brazil. High oil prices just before the crisis and at the beginning of the crisis changed the preferences of buyers toward smaller, more convenient and energy-efficient vehicles, as well as ecological vehicles for which the government provided incentives. Competitors in the industry had to adapt their products to altered demand and stricter regulations.

Despite the difficult economic circumstances, especially in developed countries, HKAG managed to compensate for the effects of the crisis. The company turned threats into opportunities and became one of the leaders in the industry after the crisis. Thanks to its marketing positioning the company was able to respond to the changes in the business environment more readily than the competitors. Their capabilities and competencies in the production of small, compact and medium vehicles at lower cost than the competitors helped them improve their competitive position. The business strategy used during the crisis implied independent development because it was estimated that it would not be possible to generate synergetic effects through acquisitions with the existing production range (Chung, 2011).

The aim of the company during the crisis was to ensure the survival through minimization of negative effects, and then to achieve growth at the expense of the troubled leaders. This goal was achieved through reduction in operating costs, development of new technologies, increased sales of new models and improved market position. Investments in innovation during the crisis resulted in improved quality and product design. Finally, relatively balanced presence in both developed and emerging markets enabled the company to attract the wavering customers by means of localized marketing activities. Sales growth was supported by a flexible and efficient production system that allows adjustment to fluctuations in demand. 
Rakita B. et al.: Competitive strategies of late followers in auto industry: case study...

HKAG is the only car manufacturer who increased sales and improved financial performance during the crisis. While the US and European rivals engaged in survival by rationalizing excess capacity, the challenge for the company was how to meet the growing global demand (Automotive News Europe, 2011). During the crisis the company followed the strategy of balanced global presence by combining export strategy and the strategy of multi-domestic structure (Chung, 2014). The company carefully invested in creation of new capacities abroad, and simultaneously raised the level of their utilization. HMC Global Utilization Trend shows an increase in the capacity utilization from $89.9 \%$ in 2008 to $108.4 \%$ in 2012 , meaning that the desired economy of scale was achieved (HMC, 2015b).

Nowadays to achieve success in automotive industry it is much more important to compete in the development of new products because the leading car manufacturers have already reached high levels of production efficiency. During the crisis, the company developed capabilities for development of new models and thus responded more readily to changes in demand. The time needed to develop a new model was shortened from 40 months in 2002 to 19 months in 2013 (HMC, 2015b). In order to respond quickly to changes in consumer preferences the company had to strengthen the link between sales and production. This was the result of improved communication with suppliers and dealers as the most important stakeholders. Reliable vertically integrated and independent suppliers enabled the company to expand product portfolio, develop new models and improve production efficiency (Lee, 2011). To reduce costs and the risk of foreign currency fluctuations the emphasis was placed on cooperation with local suppliers, who internationalized their business by following their client around the world.

During the crisis, the company made huge interventions to redefine marketing strategy. They also sought to improve and coordinate all elements of the marketing mix.

The production range of the company comprises all segments, from small cars to large/medium-sized sedans and SUV (sports utility vehicle). The main focus of Hyundai and Kia brands is on small and medium-sized sedans. Following the trend of polarization of demand during the crisis, the company offered enhanced small and compact cars with excellent value for money. During the period 2008-2009, the company launched premium and luxury sedans Genesis/Equus at lower prices than its competitors with the aim of shifting towards higher market segments and sales of products with higher profit margins.

Shioji \& Tomiyama (2015) pointed out that during the crisis HMC implemented selective focused local adaptation strategy in BRIC markets and other large emerging markets. HMC does not sell specially designed models in these 
Rakita B. et al.: Competitive strategies of late followers in auto industry: case study...

markets, but their Korean models adapted to each market individually. The level of quality, specifications and prices of vehicles are adapted to each country.

The rapid growth and increasing diversity of the assortment increased the overall complexity of the business which required efficient management of product life cycles (Automotive News Europe, 2011). Growing business complexity increases the risk of failing to sustain and improve the quality of products and the risk of recall of vehicles from the market, which usually implies high costs. Nevertheless, unlike their rivals, the company did not have major problems in this field.

In automotive industry, quality and reliability of a car to a large extent determine the success of a car company (Chung \& Kim, 2014). In order to improve the quality of their vehicles during the crisis, HKAG constantly invested in new technologies, and by providing a long warranty period the company sent the message that they strongly believe in the quality of their products. According to J.D. Power's Initial Quality Study US, in 2009 HMC took first place in terms of quality in the category of mass market brands.

When the customers were fully convinced of the reliability of their vehicles, the company took some actions to improve the product design, so, among other things, hired some well-known designers such as Peter Schreyer, who had worked for Audi.

Hyundai and Kia were running the risk of cannibalism because they were serving similar market segments, so these two brands had to be clearly differentiated. Design centers have been separated, exchange of personnel is prohibited, and each factory produces vehicles of a single brand (Chung \& Kim, 2014). However, Hyundai and Kia share production platforms in order to achieve economy of scale. Everything that is visible to customers is subject to differentiation. However, these two companies to a large extent share all that customers do not see.

Before the crisis, Hyundai was positioned as a brand for the mass market i.e. a "value for money" brand. However, brand loyalty in this segment is relatively small. Customer loyalty increased with the improvement of the vehicle quality. In addition to quality improvement, sponsorship of sporting events and successful repositioning towards "green" and premium vehicles contributed to brand value growth (Chung, 2011). From 2011, Hyundai brand was repositioned from "value for money" brand to "modern premium" brand offering premium quality, attractive design and modern technology to mass market. Higher brand value enabled price increase and achievement of higher profit margins with a growing volume of production (Automotive News Europe, 2011, Automotive News Europe, 2015). 
Rakita B. et al.: Competitive strategies of late followers in auto industry: case study...

HMC endeavors to attract more mobile and career oriented customers with the image of a brand that is "sophisticated, smooth and reliable." Kia is focused towards the younger generation and goes for the image of a brand that is exciting and accessible (Chung \& Kim, 2014). HKAG does not have a low-cost brand like Renault's Dacia. Hyundai has launched a low-cost local brand only in China to meet the requirements of Chinese government. The company did not have a stand-alone premium brand because its launch during the crisis would increase the costs and the risk of failure would be very high (Automotive News Europe, 2011).

During the crisis, the company insisted on price competitiveness by offering customers high value for the price. Value price strategy is based on economy of scale in production and product development, a high level of capacity utilization and low level of stocks at the global level. Although they offered lower prices than their rivals during the crisis years, HMC managed to realize extremely high profit margins for a mass market car manufacturer. Operating profit margin grew in the period from $2008(3.9 \%)$ to $2011(10.3 \%)$, and a downward trend was recorded in the period from $2012(10.00 \%)$ to 2015 (6.9\%) (HMC, 2014b. HMC, 2016a). High profit margins were the result of small promotional discounts because the demand for their products was relatively high (Holstein, 2013). Free trade agreements between South Korea and the EU and the United States concluded in 2011 and 2012 respectively had positive impact on the price competitiveness of the company (Soeun, 2011).

By shifting from the cost leadership strategy to the strategy of differentiation, HMC has significantly increased the prices of their products. In the period 2013-2015, depending on the model, this improvement was between 17 percent and 32 percent from the A-segment to the E-segment (Automotive News Europe, 2015). The brand value growth and the incremental change in the sales structure contributed to the average selling price increase from USD 12,400 in 2009 to USD 15,700 in 2013 (HMC, 2015c).

The growth in sales during the crisis, expansion of product range and brand repositioning towards a modern premium required establishment of an efficient dealer and sales network. The network is characterized by local adaptation through differentiated innovative services before and after sale, which increases customer satisfaction and loyalty. Delivering vehicle for a test drive to the address of the potential customer, before service (free vehicle check before failure) and home-to-home service (taking a vehicle from the customer for a service and returning it to the customer after the service) stand out among these innovative services offered by the company. Dealers play an important role in preserving competitiveness of a company in a crisis period because they are closely related to the purchase, financing and servicing. In 2008, HMC invested more than USD 74 million in building up the dealer 
Rakita B. et al.: Competitive strategies of late followers in auto industry: case study...

network in Europe (Ritter, 2010). The company sought to reduce the number of dealers, but to increase the number of showrooms per dealer, in order to improve the efficiency of business operations (Automotive News Europe, 2011). From 2009, the company has redesigned dealer showrooms based the new global design standards, has implemented a training program for dealers, and Hyundai and Kia brands have separate dealer networks.

During the crisis promotion was aimed at encouraging wavering customers to realize the purchase and increase brand awareness among customers. The company concluded that the US customers were delaying the purchase of vehicles for fear of losing their jobs. Therefore, in 2009 the company launched Hyundai Assurance program which allowed customers to return the car a year after the purchase in case of losing their jobs (Chung, 2011). The program was promoted through the message "We are here for you; we are in this with you." The message was communicated through the dealer newspaper ads, internet banners, and even through corporate advertising spots. Speed of implementation and cooperation between the sales and marketing were of great importance for the success of the campaign (Dickie \& Trailer, 2010). Additional incentives for the US customers were lower fuel prices for a period of one year, interest-free credits and favorable leasing contracts for which the funds were provided by the sister company Hyundai Finance. During the crisis, the company offered five-year unlimited warranty for vehicles, five years of roadside assistance and five years of vehicle health checks, called the Triple 5 package. This proved to be a good move, so the company increased its market share in the US from 3\% in 2008 to $4.6 \%$ in 2013 (HMC, 2014b).

To raise customer brand awareness, which is considered to be the weakest point of the company, significant funds were invested in advertising during sporting, cultural and entertainment events. The largest funds given for sponsorship were related to football, but the sponsorship activities gradually spread to cricket and golf in 2011 and ski jumps in 2012. Significant resources were invested in digital marketing in order to improve communication with modern customers focused on premium brand.

Traditional promotional activities such as participation in car shows have not been neglected. Hyundai and Kia perform separately at fairs and their booths are located far from each other. This encourages differentiation between brands and prevents the risk of cannibalization (Automotive News Europe, 2011). 
Rakita B. et al.: Competitive strategies of late followers in auto industry: case study...

\section{Post-crisis competitive strategies of the late followers in automotive industry - HKAG}

After a series of successful business years, 2015 was a challenging year for HKAG although the operational and financial performance was satisfactory. Sales growth was relatively small, while operating profit fell compared to the previous year due to the strengthening of the domestic currency and additional investment in promotional activities. Time of double-digit sales growth is a thing of the past. For the year 2016, the company, therefore, predicted a combined 1.6\% increase in global sales (Nam, 2016).

Some analysts have looked with suspicion on the success of HMC in the global auto market. They explained it by the following short-term factors that were especially pronounced during the global economic crisis: 1. high oil prices that were held by the end of the third quarter of 20142 . the business problems of Toyota and the US competitors, and 3. appreciation JPY and USD against KRW on foreign exchange markets.

According to Bloomberg (2016), oil prices fell at the beginning of the global economic crisis and then rebounded exceeding the price of 100 USD per barrel. Such high prices have been sustained until the second half of 2014 , which in combination with lower incomes and lower employment pushed up the demand for smaller and energy-efficient vehicles, which HKAG has in its portfolio. However, at the end of 2014 , oil prices started their downfall falling below 30 USD per barrel in early 2016 (Bloomberg, 2016). The oil price fell and the recovery in economic activity had a positive effect on the demand for larger vehicles typically produced by the US manufacturers and Toyota. In recent years, these companies have managed to stabilize their business and are now trying to regain once lost positions.

Fluctuation of domestic currencies against the currencies of major competitors and the largest markets is an external factor that largely defines competitiveness of carmakers. High degree of local production reduces exposure to exchange rate fluctuations (Warburton, Quettawala, Zhu, \& Wen, 2013). By contrast, by the beginning of the crisis HKAG significantly concentrated production in the home country. Although the centralization of production helped the company achieve economy of scale, it exposed the group to the risk of exchange rates fluctuations. From 2008 to the end of 2013, KRW was significantly weaker than the USD and JPY, which enabled HKAG to take over a share of European and the US market from Japanese competitors. The situation changed significantly in 2013 and 2014 when KRW strengthened against the JPY and USD (See figure 1). This reduced HKAG net profit and undermined their position in the global auto market, especially in relation to Japanese rivals in foreign markets (Warburton et al., 2013). 
Rakita B. et al.: Competitive strategies of late followers in auto industry: case study...

Although a late follower, the company managed to improve its market position and set the basis for challenging the leaders in the future. The success of the company in the previous period has been primarily based on internal capabilities and competencies, rather than short-term external factors. Future strategic position of the company will depend on their ability to further develop internal capabilities and competencies through 1 . improvements in the quality of the vehicles 2. investment in R\&D and 3. brand building. Several important external factors, namely 1 . changes in consumer preferences and geographic distribution of demand and 2. domestic currency fluctuations, will be another contributory factor.

Figure 1. HMC and Kia Motors: Global sales \& JPY/KRW exchange rate

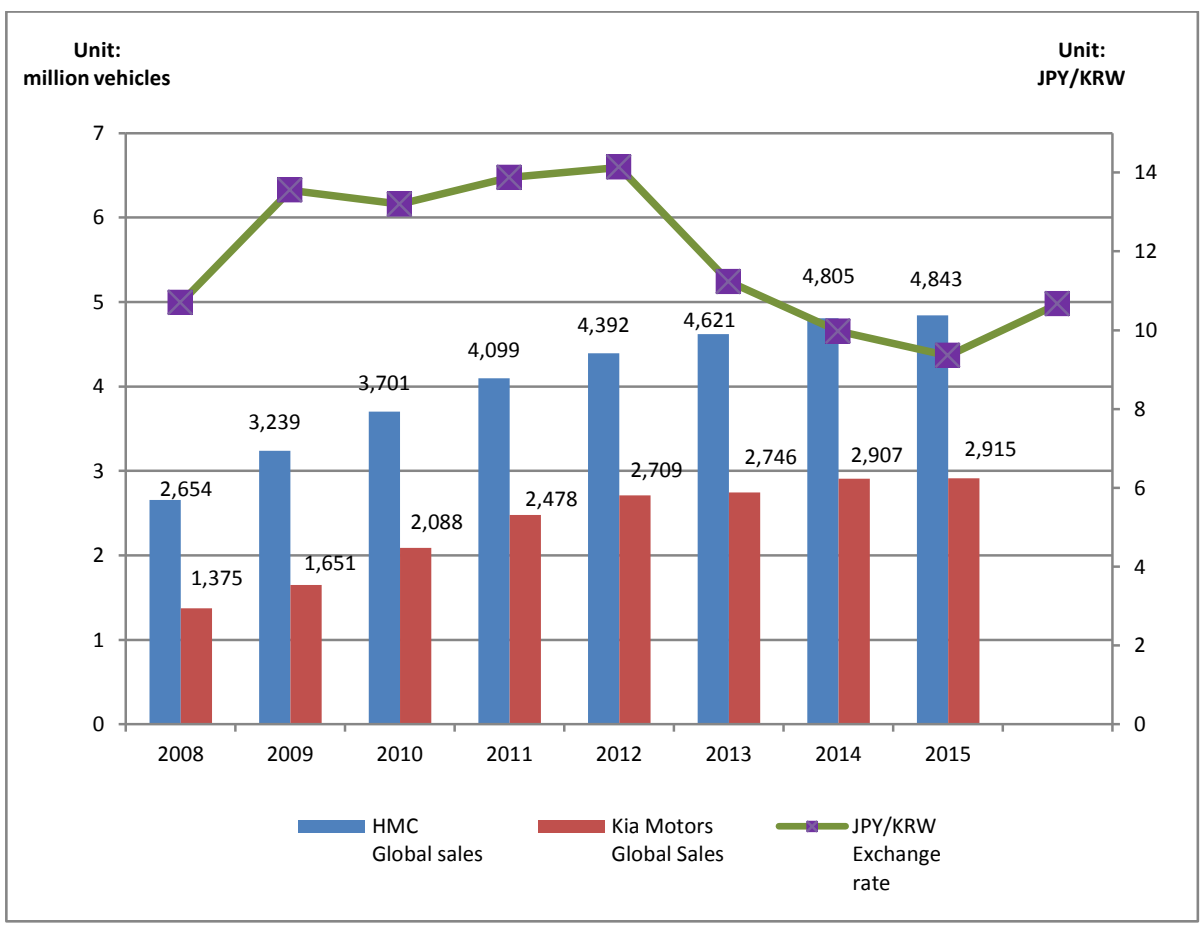

Source: HMC and Kia Motors official reports, Usforex

J.D. Power 2015 US Initial Quality Study (IQS) assesses the problems that vehicle owners face 90 days after the purchase. Research comprises 48 thousand car owners. In 2015, according to this study, Kia ranked second behind Porsche, while Hyundai ranked fourth behind Jaguar. Global competitors in auto industry were shocked by this study because it showed 
Rakita B. et al.: Competitive strategies of late followers in auto industry: case study...

that Hyundai and Kia surpassed Japanese rivals in terms of vehicle quality (J.D. Power, 2015).

In order to maintain its leading position in terms of quality, HKAG will have to invest significantly in R\&D. In 2014, HMC invested over EUR 1.4 billion in $R \& D$ with R\&D intensity of $2.1 \%$, while Kia invested almost EUR 840 million with R\&D intensity of $2.4 \%$ (European Commission, 2015). HKAG group is significantly lagging behind in terms of the absolute amount of investment and $R \& D$ intensity compared with the leaders in the industry. VW investments in R\&D amounted to over EUR 13 billion; Toyota invested nearly EUR 7 billion, while General Motors spent over 6 billion EUR (European Commission, 2015). Given that investment in R\&D represents long-term growth driver, HKAG plans to scale it up by 2018. Despite a relatively modest investment in R\&D compared with the major competitors, HKAG group has managed to achieve significant results in terms of quality, which can only be explained by greater productivity of investments.

The real challenge for the company will be to transform customer satisfaction with the brand quality into brand loyalty which will attract new customers. According to Interbrand, the value of the Hyundai brand in 2015 was estimated at nearly USD 11.298 billion, an increase of $8 \%$ compared to the previous year, while the Kia brand was worth almost USD 5.7 billion (See figure 2). In terms of brand value in 2015, Hyundai and Kia ranked 7th and 11 th in the list of brands in automotive industry. Hyundai's brand value grew slightly compared to the industry average, while the Kia brand's growth was below the industry average. It turned out that the implementation of "modern premium" in 2011 was an important HMC's strategic decision because the brand value has been increasing by $18 \%$ on average each year (HMC, 2016a).

Recovery in demand and its geographic distribution will significantly affect development of the company. According to OICA, starting from 2009, global sales were constantly growing and reached almost 90 million units at the end of 2015. In 2015, global automotive industry enjoyed a period of relatively strong growth and profitability. Annual sales reached before-the-crisis levels in some regions (USA), but there is still uncertainty about future trends and growth in some major markets (Russia, Brazil and the EU).

HMC's sales were relatively diversified and balanced across regions. Domestic market accounted for almost $15 \%$ of sales, North America almost $19 \%$, Europe more than $13 \%$, Asia for over $35 \%$, while other regions accounted for $17 \%$ (HMC, 2016a). Thanks to a relatively balanced sale by regions, the company is exposed to a smaller risk of fluctuations in demand compared to major competitors who are predominantly focused on domestic and one more region. Regarding orientation to different market segments, relatively small passenger cars (A, B and $C$ class) make the largest share of 
Rakita B. et al.: Competitive strategies of late followers in auto industry: case study...

sales, over $54 \%$, larger passenger cars (D, E and $\mathrm{F}$ class) participate with $15 \%$ share, while the SUV/MPV models (multi-purpose vehicle i.e. minivan) make less than $23 \%$ of sales (HMC, 2016a).

Figure 2. Carmakers' brand value (billion USD)

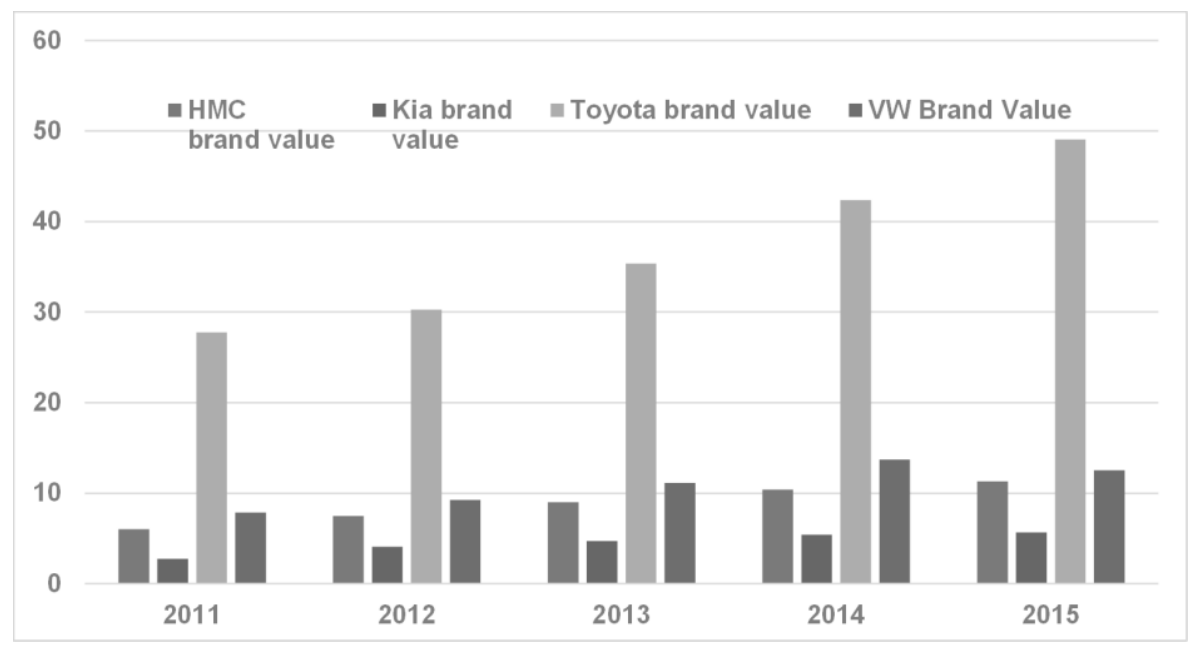

Source: Interbrand, 2015

The company did not keep up with the changes in customer preferences, and growing demand for CUV (crossover utility vehicle) and SUV, but based its development on sedans (Nam, 2015). Demand for SUV vehicles grew globally in 2015 due to low fuel prices, increased sense of safety, improved design and practicality compared to sedans, greater need for recreation and exploration of inaccessible terrain etc. The fact that HMC's factory in the United States produces only passenger vehicles, although sales of CUV and SUV vehicles in the United States in 2015 totaled over 6.5 million units (Auto Alliance, 2015) is an indicator that the company has neglected this segment.

In the last few years, high value of domestic currency has been a huge problem for the company, because it increases the cost of export of vehicles, components and parts from the Korean factories. The company has sought to reduce exposure to exchange rate fluctuations by reducing the share of exports from domestic plants in total sales to $23 \%$ in 2015 and by increasing the number of suppliers with overseas operations (HMC, 2016a). Despite lower production in domestic plants, company has managed to achieve full employment of its capacities which is of great importance for achieving economy of scale. 
Rakita B. et al.: Competitive strategies of late followers in auto industry: case study...

On the basis of the analysis of their own capabilities and competences and the changes in business environment, the company's management has concluded that it is necessary to redefine the global growth strategy. Growth in demand in the mass market will be relatively low in the near future and therefore, the company's high growth in sales as in the aftermath of the global crisis is not likely to repeat. Therefore, the company's goal is not to become a leader in the industry, but Hyundai and Kia to become the most loved brands. The company intends to continue its strategy of sustainable organic growth, and will continue with the application of hybrid competitive strategy. Cost leadership will be pursued on the basis of superior operational efficiency in production and $R \& D$, while the strategy of differentiation will be based on excellent quality and design, aggressive marketing and the transition from rational to emotional attributes.

HKAG is gradually entering the maturity phase and, therefore, besides the offensive market strategies the group needs to implement defensive market strategies as well. In the previous period, the company's aggressive moves enabled it to take the leaders' market share. However, this strategy has become more expensive and more risky due to the changes in the business environment. In the future, the offensive strategy will be based on developing and winning market segments of ecological and smart vehicles, both in mass and luxury class. Management expects that automotive industry will experience radical changes and that these relatively small segments will expand in the coming period (HMC, 2015a). To become one of the leaders in fast growing segments, the company intends to further invest in development of technological solutions necessary for servicing these segments, to improve the product development process and the quality of customer services.

In addition to winning new growing segments, it is important for the company to maintain its market share in traditional segments. Defensive strategy in traditional segments will be implemented through incremental innovation on the products, tactical sales discounts, improved distribution and dealer network and investment in promotional activities. To implement defensive strategies, it is very important to increase the retention rate of customers through successful implementation of relationship marketing.

In order to implement defensive and offensive aspects of competitive strategy, the company is working towards developing new technological solutions. The company is working on development of conventional engines with lower fuel consumption and lower emissions. HMC is planning to improve fuel efficiency by $25 \%$ on average in conventional engines by 2020 . In the area of "green" vehicles, HMC is developing cars with hybrid engines, electric vehicles and hybrid cars FCEV (fuel cell) driven by an electric engine (Jato Dynamics, 2015). The company's advancement in this area is best depicted by the fact that the Tucson IX FCEV was launched in 2013, while Toyota launched its 
Rakita B. et al.: Competitive strategies of late followers in auto industry: case study...

first FCEV vehicle in 2015. The company is planning to expand the "green" car line up to 26 models by 2020 and to become the second largest manufacturer of eco-friendly cars (HMC, 2016a).

As for the defensive aspects of the strategy, it is important to achieve economy of scale through a high level of capacity utilization and economy of scope by sharing resources. Although the capacity utilization rate was the highest in the industry, there has been a gradual decline in capacity utilization as of 2011. Therefore, establishment of new facilities needs to be aligned with sales increase in the future. In order to achieve economy of scope, the company will vertically integrate certain activities and work on the development of platforms that are used for a number of models. In 2015, the company used 6 integrated platforms and produced a total of 48 models (HMC, 2016a).

Offensive aspect of the competitiveness strategy implies a deeper penetration into the luxury market segments, which will be realized by launching independent premium brand Genesis in late 2015. Although the brand has existed since 2008, it is estimated that now is the right moment for its independence because tough competition and low growth is expected in the mass market. In order to successfully launch a luxury brand, the company has hired managers and designers who have worked with brands Lamborghini, Audi and Bentley. However, lot of patience, persistence, time and huge investments are necessary to build a luxury brand (Automotive News Europe, 2016).

Genesis will be first sold in South Korea, North America, China and the Middle East. European customers remain extremely loyal to domestic luxury brands because of the historical heritage and culture, so the brand Genesis will not be sold in Europe at an early phase. The target customers are those looking for the "new luxury": young, pragmatic people who want to impress others. Luxury cars are no longer reserved only for the rich, but the goal is to offer the functionality of higher segments at the same price. The brand Hyundai achieved the top quality with front-wheel drive, and the brand Genesis will focus on safety and models with rear-wheel drive. In the next few years, six models will be launched under the brand Genesis such as sedans, CUV, SUVs and electric cars (Automotive News Europe, 2016). Genesis models will be offered at lower prices than the competitors' in the given segment, which is similar to the strategy used by Toyota when Lexus was launched. The new brand will be initially sold in Hyundai showrooms. After the product line under the brand Genesis is completed, the company will consider opening independent showrooms. Given the growth in internet sales and marketing, the company will closely analyze trends in the industry and on the basis of cost-benefit analysis decide whether it is justifiable to establish independent distribution channels. 
Rakita B. et al.: Competitive strategies of late followers in auto industry: case study...

\section{Conclusions}

In the last few years, HKAG group as a late follower in automotive industry managed to place itself among the leading competitors. The company has gained this position by combining the strategy of organic growth and the hybrid competitive strategy. On their way to the top the company has followed Toyota's example and its development strategy. However, this paper shows that HKAG has reached and exceeded Toyota's performances by modifying its competitive strategy. The company turned the global economic crisis into an opportunity and increased its global market share with a balanced structure of global sales.

Before the crisis, the company's focus was on smaller and more fuel efficient vehicles. When the crisis began, consumer preferences shifted towards these types of vehicles so the company successfully used this opportunity to expand into the global market. An unexpected result of the study is that HKAG has become the leader in terms of productivity, which is a key indicator of competitiveness in automotive industry. In addition, J.D. Power 2015 US Initial Quality Study (IQS) showed that Hyundai and Kia surpassed Japanese rivals in terms of quality of vehicles and became a benchmark in the mass market. This supports the first research statement which states that the late followers from emerging markets focus their strategy on value for money segment which they successfully serve thanks to their low operating cost capabilities.

This research shows that the company is characterized by extremely rapid decision-making process which enables them to respond readily to changing market requirement and use growth opportunities. During the crisis, the company reacted quickly to the changing business environment, was costeffective and offered the right range of products that was in line with the changed customer preferences. The company's speed of response is reflected in reduced time needed for development of new products, rapid adjustment of the product portfolio and pioneering in launching FCEV vehicles in the segment of green vehicles. Also, the company's organizational capabilities to rapidly transfer manufacturing practices from Korea to abroad and adapt them to the local specificities allowed the expansion of production capacities in foreign countries. In spite of its rapid growth the company has remained extremely lean thanks to its superior cost structure which is the result of a significantly smaller number of production sites and workers compared with the leaders, partial vertical integration and involvement of a larger number of suppliers who do business abroad, and reduced number of integrated production platforms and a high level of capacity utilization. All this confirms the second research statement which states that the late followers from emerging markets are faster than the leaders and that they remain extremely lean regardless of their size. 
Rakita B. et al.: Competitive strategies of late followers in auto industry: case study...

This case study showed that the company invested less in R\&D in the past compared with the rivals, which can be explained by huge investment in development of global manufacturing and dealer network. Since R\&D is longterm driver of development, the company is planning to reduce the competitive gap through intensive investment in this area. The company is gradually entering the maturity phase, and, therefore, besides the offensive strategies, must consider implementation of defensive strategies, too. These strategies should be directed at incremental improvement of products in the post-crisis period, high investment in sales promotion, increasing brand value and customer loyalty. All this supports the third research statement which assumes that the late followers in automotive industry invest less in R\&D and have a lower brand value compared with the leaders.

Analysis of the company's business performance in the post-crisis period showed that its further development involves certain risks. Oil prices fell drastically, and so did the demand for fuel-efficient sedans, in production of which HMC possesses competitive advantage, while the demand for SUV and CUV models increased. HMC has neglected these segments, but it is expected that Kia will improve SUV/CUV assortment because it has a wider range of capabilities and larger experience in development and production of light trucks. In 2015, KRW strengthened and thus compromised the low-cost strategy. Moreover, the major rivals recovered after the crisis and intensified competition in the rapidly growing markets that are essential for the company.

This research showed that the company responded readily to the changed circumstances by using offensive strategies in the market segments of "green" and smart cars in the premium and mass market, but that its insufficiently diversified range of SUV/CUV vehicles remains the weak point in the post-crisis period. Launching of the independent premium brand Genesis is seen as the opportunity to increase sales and profit. This supports the fourth research statement which states that the late followers in the automotive industry who want to challenge the leaders have to make shift towards luxury and green market segments.

\section{References}

Abrami, M.R., Kirby, W.C., \& McFarlan, F.W. (2014). Why China Can't Innovate and What It's Doing about It. Harvard Business Review, 92(3), 107-111. Retrieved from www.hbr.org

-Auto Alliance. (2015). Auto marketplace: Popular vehicles. Retrieved from http://www.autoalliance.org/auto-marketplace/popular-vehicles

Barnard, H. (2010). Overcoming the Liability of Foreignness without Strong Firm Capabilities: The Value of Market Based Resources. Journal of International Management, 16(2), 165-176. doi:10.1016/j.intman.2010.03.007 
Rakita B. et al.: Competitive strategies of late followers in auto industry: case study...

Barney, J., \& Tong, W.T. (2006). Building versus Acquiring Resources. In G. Abby, O. Nicholas, G. David, \& V. Howard (Eds.), Strategy and Performance Achieving Competitive Advantage in the Global Marketplace. (pp. 57-81). London, UK: Middlesex University Business School.

Barney, J. (1991). Firm Resources and Sustained Competitive Advantage. Journal of Management, 17(1), 99-120. doi:10.1177/014920639101700108

Becerra, M. (2009). Theory of Firm for Strategic Management: Economic Value Analysis. New York, USA: Cambridge University Press.

Beishaar, H., Knight, J., \& van Wassenaer, A. (2001). Deals that Create Value. The McKinsey Quarterly, 37(1), 65-73. Retrieved from http://www.mckinsey.com/quarterly/overview

-Bloomberg. (2016). Energy. Retrieved from http://www.bloomberg.com/energy

Boulding, W., \& Christen, M. (2001). First Mover Disadvantage. Harv Bus Rev, 79(9), 20-21. Retrieved from www.hbr.org

Boyer, R., \& Freyssenet, M. (2006). The world that changed the machine: An analysis schema of productive models. Retrieved from http://www.freyssenet.com/files/Lettre,\%20The\%20World\%20that\%20changed\% 20the\%20machine.pdf

Christensen, M.C., Alton, R., Rising, C., \& Walderck, A. (2011). The Big Idea: The New $\mathrm{M}$ and A Playbook. Harvard Business Review, 89(3), 49-57. Retrieved from www.hbr.org

Chung, K.W., \& Kim, Y.J. (2014). Hyundai Motor Company: Design takes the driver's seat. DMI Case Studies. (pp. 20-21). Harvard Business School Publishing. Retrieved

from http://c.ymcdn.com/sites/www.dmi.org/resource/resmgr/pdf_files/Hyundai_Case_ Study3d.pdf

Chung, M.K. (2011). Turning crisis into opportunity: Are korean automobile firms in the leap forward in the new century?. In: 19th International Gerpisa Colloquium, Paris, France. 1. June 8-10. Retrieved from http://leblog.gerpisa.org/en/comment/reply/1228\#comment-form

Chung, M.K. (2014). Production System of Beijing Hyundai Motor in China: Catch up Strategy for a Latecomer. In: 22nd International Gerpisa Colloqium, Kyoto, Japan. June 4-6. Retrieved from http://gerpisa.org/node/2448

Dickie, J., \& Trailer, B. (2010). Sales Management 2.0: Optimizing Sales Performance $2010 . \quad$ Volume 2.. $\quad$ Retrieved from http://marketinginteractions.typepad.com/Sales-Management-2.0-e-Book-Vol2Mkt-Interactions.pdf

-European Commission, (2015). 2009-2015 EU Industrial R\&D Investment Scoreboard. Economics of Industrial Research and Innovation. Retrieved from http://iri.jrc.ec.europa.eu/scoreboard.html

Fujimoto, T., \& Takeishi, A. (2001). Automobiles: Strategy-based Lean Production System. Japan: The University of Tokyo / Hitotsubashi University. Retrieved from http://www.cirje.e.u-tokyo.ac.jp/research/dp/2001/2001cf121.pdf.

Gubbi, R.S., Aulakh, S.P., Ray, S., Sarkar, M.B., \& Chitoor, R. (2010). Do International Acquisitions by Emerging Economy Firms Create Shareholder Value?, The Case of Indian Firms. Journal of International Business Studies, 41(3), 397-418. doi:10.1057/jibs.2009.47

Holstein, W. (2013). Hyundai's capabilities play. February 26.. Retrieved from http://www.strategy-business.com/article/00162?gko=8346f 
Rakita B. et al.: Competitive strategies of late followers in auto industry: case study...

Retrieved from https://autoassembly.mckinsey.com/ourknowledge/all/all/view/Profiling_South_K orea_Automotive_Industry

-Hyundai Motor Company. (2013). Hyundai Annual report 2012. Retrieved from http://worldwide.hyundai.com/wcm/idc/groups/sggeneralcontent/@hmc/documen ts/sitecontent/mdaw/mdcz/ edisp/hw073495.pdf

-Hyundai Motor Company. (2013). Hyundai Investor presentation. February. Retrieved from

http://www.hyundai.com/wcm/idc/groups/sggeneralcontent/@hmc/documents/sit econtent/mdaw/mdcx/ edisp/hw071209.pdf

-Hyundai Motor Company. (2014). Hyundai Annual report 2013. Retrieved from http://worldwide.hyundai.com/wcm/idc/groups/sggeneralcontent/@hmc/documen ts/sitecontent/mdaw/mdg1/ edisp/hw085130.pdf

-Hyundai Motor Company. (2014). Hyundai Investor presentation. August.. Retrieved from

http://worldwide.hyundai.com/wcm/idc/groups/sggeneralcontent/@hmc/documen ts/sitecontent/mdaw/mdg1/ edisp/hw085043.pdf

-Hyundai Motor Company. (2015). Hyundai Annual report 2014. Retrieved from http://worldwide.hyundai.com/wcm/idc/groups/sggeneralcontent/@hmc/documen ts/sitecontent/mdaw/mtaz/ edisp/hw103155.pdf

-Hyundai Motor Company. (2015). Hyundai Investor presentation. September. Retrieved from http://worldwide.hyundai.com/wcm/idc/groups/sggeneralcontent/@hmc/documen ts/sitecontent/mdaw/mta0/ edisp/hw104064.pdf

-Hyundai Motor Company. (2015). Hyundai Investor presentation. February.. Retrieved from

http://worldwide.hyundai.com/wcm/idc/groups/sggeneralcontent/@hmc/documen ts/sitecontent/mdaw/mdk0/ edisp/hw094842.pdf

-Hyundai Motor Company. (2016). Hyundai Investor presentation. May.. Retrieved from http://worldwide.hyundai.com/wcm/idc/groups/sggeneralcontent/@hmc/documen ts/sitecontent/mdaw/mtex/ edisp/hw111176.pdf

-Hyundai Motor Company. (2016). Hyundai 2016 Quick facts. April.. Retrieved from http://globalpr.hyundai.com/imagefile/prCenter/download/Factbook_29_all_page s_V8.pdf

-Interbrand. (2015). Best global brands rankings. Retrieved from http://interbrand.com/best-brands/best-global-brands/2015/ranking/.

Isobe, T., Makino, S., \& Montgomery, B.D. (2000). Resources Commitment, Entry Timing, and Market Performance of Foreign Direct Investment in Emerging Economies: The Case of Japanese International Joint Ventures in China. Academy of Management Journal, 43(3), 468-484. Retrieved from www.jstore.org

-J.D. Power. (2015). Korean brands lead industry in initial quality, while Japanese brands struggle to keep up with pace of improvement. June 17.. Retrieved from https://www.jdpower.com/sites/default/files/2015080 IQS.pdf

-Jato Dynamics. (2015). From fiction to reality: The evolution of electric vehicles 20132015. (p. 13). November. Retrieved from http://www.jato.com/wpcontent/uploads/2015/11/JATO-White-Paper_From-Fiction-To-Reality-TheEvolution-of-EVs-FINAL.pdf 
Rakita B. et al.: Competitive strategies of late followers in auto industry: case study...

Johanson, J., \& Vahlne, J. (1977). The Internationalization Process of the Firm: A Model of Knowledge Development and Increasing Foreign Market Commitments. Journal of International Business Studies, 43(1), 23-32. Retrieved from www.jstore.org

Kale, P. (2009). The Global Indian Firms: Growth \& Value Creation through Overseas Acquisitions. The Indian Journal of Industrial Relations, 45(1), 41-52. Retrieved from www.jstore.org

Kaličanin, Đ. (2008). A Question of Strategy: To be Pioneer or a Follower?. Economic Annals, 52(177), 89-102. doi:10.2298/EKA08177089K.

-KAMA. (2013). Korean Automobile Industry: Annual Report. Retrieved from http://www.dgfez.go.kr/eng/img/download/Automotive_Industry-2.pdf

-Kia Motors. (2016). Annual report 2015. Retrieved from pr.kia.com/file/downloadBlb.do?fil_sn=F200006047

Kim, W.J. (2015). Transformation towards overseas-oriented expansion: The evolution of Hyundai Motor Group's production structure. Journal of Economics and Political Economy., 2(2), 235-261. Retrieved from http://www.kspjournals.org/index.php/JEPE/article/view/223.

Knoerich, J. (2010). Gaining from the Global Ambitions of Emerging Economy Enterprises: An Analysis of the Decision to Sell a German Firm to a Chinese Acquirer. Journal of International Management, 16(2), 177-191. doi:10.1016/j.intman.2010.03.008

Koreans coming on strong. Automotive News Europe, (2011). 2(2), 14-23. June.

Lee, B., \& Jo, H. (2006). Mutagenization of Toyota Production System: The Story of Hyundai Motor Company. Korea University - Graduate School of Labor Studies. Retrieved from http://www.korealabor.ac.kr/upload/board_data/HMcaseofTPS[\%EC\%9D\%B4\% EB\%B3\%91\%ED\%9B\%88\%EC\%A1\%B0\%ED\%98\%95\%EC\%A0\%9C].doc

Lee, C.Y. (2011). The rise of Korean automobile industry: Analysis and suggestions. Zenith International Journal of Multidisciplinary Research, ssue, 1(6), $429 . \quad$ October.. Retrieved from http://www.zenithresearch.org.in/images/stories/pdf/2011/Oct/ZIJMR/30_vol1_issue-6_\%20Choong\%20Y.\%20Lee.pdf

Li, J., Li, Y., \& Shapiro, D. (2012). Knowledge Seeking and Outward FDI of Emerging Market Firms: Moderating Effect of Inward FDI. Global Strategy Journal, 2(4), 277-295. doi:10.1111/j.2042-5805.2012.01042.x

Lieberman, M.B., \& Montgomery, D.B. (1988). First-mover advantages. Strategic Management Journal, 9(S1), 41-58. doi:10.1002/smj.4250090706

Luo, Y. (2002). Multinational Enterprises in Emerging Markets. Copenhagen, Denmark: Copenhagen Business School Press.

Luo, Y., Sun, J., \& Wang, S.L. (2011). Emerging Economies Copycats: Capability, Environment and Strategy. Academy of Management Perspectives, 25(2), 3756. Retrieved from www.aom.org

Macduffie, J.P., \& Fujimoto, T. (2010). Why Dinosaurs Will Keep Ruling the Auto Industry. Harvard Business Review, 88(6), 23-25. Retrieved from www.hbr.org

-McKinsey Global Institute. (2015). Playing to win: The new global competition for corporate profits. (pp. 9-47). McKinsey\&Company. September,. Retrieved from http://www.mckinsey.com/ /media/McKinsey/Business\%20Functions/Strategy\% 20 and $\% 20$ Corporate\%20Finance/Our\%20Insights/The\%20new\%20global\%20co mpetition\%20for\%20corporate\%20profits/MGl\%20Global\%2 
Rakita B. et al.: Competitive strategies of late followers in auto industry: case study...

Nam, I. (2015). Hyundai loses traction in fight to lift profit. July 2.. Retrieved from http://www.wsj.com/articles/SB106221463530718048678045810835209755200 98

Nam, I. (2016). Hyundai, Kia expect tough business conditions in 2016. The Wall Street Journal, Retrieved from http://www.wsj.com/articles/hyundai-motor-groupexpects-tough-business-conditions-in-2016-1451865326 2016 Jan 4.

OICA., (2015). Registrations or sales of new vehicles: All types. Retrieved from http://www.oica.net/wp-content/uploads//total-sales-20151.pdf

Ray, S., \& Gubbi, R.S. (2009). International Acquisitions by Indian Firms: Implications for Research on Emerging Multinationals. The Indian Journal of Industrial Relations, 45(1), 11-26. Retrieved from www.jstore.org

Ritter, L. (2010). The rise and competitiveness of South Korean automobile manufacturers: A comparative study with German auto producers. (pp. 32-65). USA: Auckland University of Technology - School of Business. Master's thesis. Retrieved

from http://aut.researchgateway.ac.nz/bitstream/handle/10292/1025/RitterL2.pdf?seq uence $=4$

Rugman, A. (2009). Theoretical aspects of MNCS from emerging economies. In R. Ramurti \& J. Singh (Eds.), Emerging Multinationals in Emerging Markets. (pp. 42-63). Cambridge, UK: Cambridge University Press.

Shankar, V., Carpenter, G.S., \& Krishnamurthi, L. (1998). Late Mover Advantage: How Innovative Late Entrants Outsell Pioneers. Journal of Marketing Research, 35(1), 54-70. Retrieved from http://www.venkyshankar.com/download/Shank doi:10.2307/3151930

Shioji, H., \& Tomiyama, E. (2015). Hyundai Motor Company's selective focused local adaptation strategy from the perspective of global marketing. The Northeast Asian Economic Review, 3(2), 69-80. October. Retrieved from http://www.erina.or.jp/wp-content/uploads/2015/11/naer32_tssc.pdf

Soeun, K. (2011). South-Korea-EU Free Trade: The deal's automotive impact. McKinsey\&Company, Automotive\&Assembly. Retrieved from https://autoassembly.mckinsey.com/ourknowledge/industry/Automotive/view/Sou th_Korea_EU_trade_2011-09

Suarez, F.F., \& Lanzolla, G. (2005). The half-truth of first-mover advantage. Harv Bus Rev, 83(4), 121-7. pmid:15807045

Suarez, F.F., \& Lanzolla, G. (2007). The Role of Environmental Dynamics in Building a First Mover Advantage Theory. Academy of Management Review, 32(2), 377392. Retrieved from www.aom.org

The book of Genesis: How Hyundai plans to do luxury. Automotive News Europe, (2016). January $4 . . \quad$ Retrieved from http://www.autonews.com/article/20160104/OEM03/301049922/the-book-ofgenesis:-how-hyundai-plans-to-do

-Toyota Motor Corporation. (2014). Toyota Annual report year ended. March 31. Retrieved from http://www.toyotaglobal.com/pages/contents/investors/ir_library/annual/pdf/2014/ar14_e.pdf

Vernon, R. (1966). International Investment and International Trade in the Product Cycle. Quarterly Journal of Economics, 80(2), 190-207. doi:10.2307/1880689

Volkswagen, (2015). Volkswagen Annual report 2014. Retrieved from http://www.volkswagenag.com/content/vwcorp/content/en/misc/pdf- 
Rakita B. et al.: Competitive strategies of late followers in auto industry: case study...

dummies.bin.html/downloadfilelist/downloadfile/downloadfile_30/file/Y_2014_e.p df

Warburton, M., Quettawala, A., Zhu, R., \& Wen, B. (2013). Is it possible to pick auto stocks in a period of currency volatility?. In Global autos: Currency wars. part 1, July 2. Bernstein Research.. Retrieved from https://autoassembly.mckinsey.com/download/articles/McK A\&A Extranet Bern stein Report Curremcy War.pdf

Why Hyundai Europe expects leveling off after record-breaking. Automotive News Europe, (2015). September 11.. Retrieved from http://europe.autonews.com/article/20150911/ANE/150919991/why-hyundaieurope-expects-leveling-off-after-record-breaking-2015 1/3

Williamson, J.P. (2010). Cost Innovation: Preparing for a 'Value-for-Money' Revolution. Long Range Planning, 43(2-3), 343-353. doi:10.1016/j.Irp.2009.07.008 